\title{
Effects of Organic Fertilizer and Drying Methods on Total Phenolic Content and Antioxidant Capacity of Organic White Tea (Camellia sinensis (L.) Kuntze)
}

\author{
Emine Yurteri ${ }^{1, a}$, Aysel Özcan ${ }^{1, b}$, Fatih Seyis, ${ }^{1, c, *}$ \\ ${ }^{1}$ Field Crops Department, Faculty of Agriculture and Natural Sciences, Recep Tayyip Erdogan University, 53100 Rize, Turkey
} *Corresponding author

\begin{tabular}{|c|c|}
\hline A R T I C LE INFO & A B S T R A C T \\
\hline $\begin{array}{l}\text { Received : 29/05/2019 } \\
\text { Accepted : 04/09/2019 }\end{array}$ & $\begin{array}{l}\text { The aim of this study was to determine the effect of different fertilizer doses and drying methods on } \\
\text { total phenolic contents and antioxidant activity of organic white tea (Camellia sinensis (L.) Kuntze) } \\
\text { obtained from Hemşin Valley, region of Rize/Turkey. The determination of phenolic constituents } \\
\text { was done by the Folin-Ciocalteau method and the determination of antioxidant activity by the FRAP } \\
\text { method. The results showed that the phenolic content of white tea was as follows: } 443,7-506,2 \mu \mathrm{g} \\
\text { GAE/g DW in the drying oven, } 421,4-473,6 \mu \mathrm{g} \text { GAE/g DW in shadow and } 434,4-485,2 \mu \mathrm{g} \text { GAE/g } \\
\text { DW in the liofilizator. According to the FRAP method the antioxidant activity was as follows: } \\
1130,1-1176,9 \mathrm{mg} \mathrm{FeSO} / \mathrm{gr} \text { DW in drying oven, } 1141,2-1157,1 \mathrm{mg} \text { FeSO4/gr DW in shadow and } \\
1005,3-1183,2 \mathrm{mg} \text { FeSO4/gr DW in lyophylizator. The results revealed that different fertilizer doses } \\
\text { and drying methods had important effects on the total phenolic content and antioxidant activity of } \\
\text { white tea. }\end{array}$ \\
\hline
\end{tabular}

Polyphenol

Antioxidant

Phenolic constituents

emine.yurteri@erdogan.edu.tr

\section{Introduction}

Compared with the World the tea plant has a shorter adaptation, acceptation and cultivation history in Turkey. However, the tea plant (C. sinensis) has been accepted by the local farmers at the Black Sea Region rapidly beginning from the 1930s. Tea is probably the most widely consumed beverage in the world after water (Muktar and Ahmad, 2000). On the World tropical and subtropical areas with adequate rainfalls, good drainage, and a slightly acidic soil are the suitable conditions where this plant can be grow best (Graham, 1999).

The common tea plant is the evergreen shrub, there are several varieties of this species: one being the Indian Assam tea (C. sinensis var. assamica (J.W.Mast.) Kitam.) and the the China-type (Camellia sinensis L. Kuntze). Traditionally, tea is prepared from its dried young leaves and leaf buds, made into a beverage by steeping the leaves in boiling water. China is credited with introducing tea to the world, though the evergreen tea plant is in fact native to Southern China, North India, Myanmar and Cambodia (Hicks, 2001).
Tea contains a wide range of phenolic compounds. Tea's polyphenols include flavanols, flavandiols, flavonoids, and phenolic acids; these compounds may account for up to $30 \%$ of the dry weight of the tea leaves according to the literature (Hilal and Engelhardt, 2007). Further, tea is one of the richest sources of antioxidants and the three major forms of antioxidant tea are green tea, oolong tea, and black tea. These teas are differing in their production methods and chemical composition (Balentine et al., 1997; Lambert and Elias, 2010).

Tea production are practised in the Eastern Black Sea Region, in a zone beginning from the Georgian border up to the Fatsa district in Ordu. In this region tea production is mainly located in Rize, Ordu, Giresun, Trabzon and Artvin (Anonymous, 2016). If we are considering the tea production areas in the World these regions are located in the top zone. In Asian countries like China, India and Sri Lanka temperature does not fall up to minus degree in tea production areas and tea production is covering the whole year. But in our country where we can feel four climates 
tea plantations are in fallow four six months. The fact that snow falls on Turkish tea plantations bring them an extra important characteristic. Because of this character pesticides are not applicated in our tea production areas. This gives Turkish tea compared with teas in the World "the most natural tea" characteristic. Parallel to the developments regarding organic tea cultivation in the world ÇAYKUR initiated in 2003 studies to increase organic tea farming in our country. Within the context of organic tea farming Borçka/Artvin and Çamlıhemşin and Hemşin/Rize was chosen as organic tea production areas.

\section{Organic Fertilizers in Tea Production}

The objective of organic tea cultivation is to have an eco-friendly plantation; although aiming the conservation of ecology and natural habitat without polluting soil, air and water and yet maintaining sustainable tea production. In organic tea cultivation tea is produced in the absence of synthesized chemicals like pesticides, fungicides, herbicides, growth regulators and concentrated fertilizers (Shamsul et al., 2017).

Ren et al. (1999) and Sun et al. (2003) reported that application of organic fertilizers is one of important practical measures to improve soil fertility. In addition to providing necessary nutrients for crops and improving soil physicochemical properties, organic fertilizer is able to enhance soil microbial activity of soil, such as improving activity of soil enzymes and increasing soil microbial biomass. Organic fertilizers have traditionally been used in agricultural areas, especially in view of their benefits for the soil biological and chemical properties (Queiroz et al., 2004). It is worth remembering that the addition of organic residues is fundamental for carbon (C) recycling in the soil and can improve its physical quality Brancalião and Moraes (2008). Organic manures can be used as an alternative for the inorganic fertilizers. They release nutrients rather slowly and steadily over a longer period and also improve the soil fertility status by activating the soil microbial biomass (Ayuso et al., 1999). For decades researchers have noted the benefits of manure additions to soil, from renovating eroded sites to improving soil physical properties and fertility following centuries of manuring (Latham, 1940).

\section{White Tea}

White tea is made mainly from newly grown buds and young leaves with tiny, silvery hairs not exposed to sunlight to prevent chlorophyll production. Buds and leaves for white tea production are harvested only once a year in the early spring. Buds are plucked before they are open, then withered and air dried in the shade, under sunshine, or in a temperature-controlled room. White tea is the least processed type of tea. It is considered as a nonfermented type, however, a slight fermentation occurs since the processing lacks the step of enzyme deactivation (Kosinska and Andlauer, 2014). The tea takes its name from the silver fuzz that covers the buds which turn white after drying. Oxidation is completely avoided by ensuring there is no rolling and bruising (Owuor and Kwach, 2012).

\section{Phenolic Content in White Tea}

White tea, the least processed tea, is one of the less studied and is ascribed to have the highest content of phenolic compounds (Dias et al., 2003). White tea is composed of polyphenols, alkaloids, amino acids, carbohydrates, proteins, chlorophyll, volatile organic compounds, fluoride, aluminum, minerals and trace elements (Cabrera et al., 2003). White tea's polyphenols include flavanols, flavandiols, flavonoids, and phenolic acids, these compounds may account for up to $30 \%$ of the dry weight of the tea leaves.

White tea, obtained from the same $C$. sinensis plant as black and green varieties, may have a lower TPC due to the fact that oxidation by polyphenol oxidase is prevented in white tea processing (Astorino et al., 2012). The total phenolic content of white tea was determined by Shannon et al. (2017) as 190.24 \pm 7.73 . Further the extraction efficiency of different concentrations of aqueous ethanol, temperature and time for the extraction of total polyphenols from white tea leaves was investigated using a central composite design. The total phenolic content in the white tea extracts ranged from 20.93 to $178.70 \mathrm{mg}$ as GAE/g DW (Peiró et al., 2014).

\section{Antioxidant Activity in White Tea}

Tea polyphenols have great medicinal and health benefits and they are potent source of antioxidants (Sharangi, 2009). In spite of numerous data about the phenolic constituents, antioxidant activity and ameliorating effects of green and black tea on human health, little is known in this sense about white tea, which is the rarest and the least processed tea (Rusak et al., 2008). White tea is just made by drying only without any other normal fermentation process which is adopted for other tea varieties. The biochemical components like flavonoids, total polyphenols, tannins and catechins are prominent in white tea. Catechin content is higher than tannin content. All those active components are higher in methanolic extracts than their corresponding aqueous extracts. The higher antioxidant activities are manifestations of all those active components (Saha et al., 2017).

Effect of different factors on tea quality have been conducted like the analysis of chemical constituents analysis of white tea of different qualities and different storage times (Ning et al., 2016), but studies on the effect of organic fertilizer and drying method together on phenolic content and antioxidant activity on white tea samples have not been conducted.

A tea plantation in the Apso settlement, located in the Hemşin valley, Rize was chosen as study area. Organic fertilizer was applied as $1000 \mathrm{~kg} / \mathrm{ha}, 1500 \mathrm{~kg} / \mathrm{ha}$ and 2000 $\mathrm{kg} / \mathrm{ha}$ as sole doses (March) compared with control (no organic fertilizer) application. The aim of this study was to determine the effect of organic fertilizer and different drying methods on yield, total phenolic content and antioxidant capacity in white tea. As far we know it's the first study in Turkey investigating the effect of different drying methods and organic fertilizer applications on phenolic content and antioxidant activity of white tea.

\section{Material and Methods}

\section{Material}

An organic fertilizer with $\mathrm{pH}=8.2$ and containing N-P$\mathrm{K}$ at ratios of 7-2-6\% respectively was used as sole doses $(0 \mathrm{~kg} / \mathrm{ha}, 5000 \mathrm{~kg} / \mathrm{ha}, 1000 \mathrm{~kg} / \mathrm{ha}, 1500 \mathrm{~kg} / \mathrm{ha}$ and 2000 $\mathrm{kg} / \mathrm{ha}$ ) in the present study. A tea plantation in the organic tea plantation area in Hemşin, Rize/Turkey was used as research area. 


\section{Methods}

A field trial according to randomized block design with three replications was conducted. Organic fertilizer doses were applied in March 2017. First shoot harvest was performed in May 2017, which were used for phenolic content and antioxidant activity analysis.

\section{Drying Methods}

- Drying oven: Fresh white tea samples were dried in a drying oven trademark Binder at $35^{\circ} \mathrm{C}$ for up to balanced dry weight.

- Shadow: Fresh white tea samples were dried in shadow for up to balanced dry weight.

- Lyophilizator: Lyophilizators are used to remove water from fast putrescent products to extend their validity life and to simplify their transportation. Lyophilization process is known as - freeze-drying is based on sublimation. The sample in chamber is freezed and the pressure reduced, water from the sample is removed without disrupting the structure of the material. Fresh white tea samples were dried for 34 hours at $-80^{\circ} \mathrm{C}$ de in a lyophilizator trademark Labomar up to balanced dry weight.

\section{Statistical Analysis}

Analysis of variance (ANOVA) was used to assess the influence of different drying methods and organic fertlizer doses on the phenolic content and antioxidant activity of tea samples obtained from the present research conducted in the Apso settlement, Pazar/Rize, Turkey. All analyses were conducted with SPSS 20.0 and the $F$ ratio was considered significant at $\mathrm{P}=0.05$ and high significant at $\mathrm{P}=0.01$. Graphics were created using Excel 2016.

\section{Determination of Total Phenolic content}

The total phenolic content of collected samples were determined using UV-Vis spectrophotometer as $\mathrm{mg}$ GAE/gr DW. The pre-treatment of samples was the same as described in the FRAP method. Gallic acid was used as standard, according to the method described by the International Organization for Standardization (ISO) 14502-1. Sample extract as $1 / 10$ of the total volume and $300 \mu \mathrm{L} \mathrm{Na} \mathrm{CO}_{3}$ was added to tubes containing water involving Folin reagent and all tubes were keep waiting in a ultrasonic shaker $\left(50^{\circ} \mathrm{C}\right)$ for $15 \mathrm{~min}$. The measurement were done using a UV spectrophotometer device at a wave length of $765 \mathrm{~nm}$ to obtain the absorbance values.

\section{Determination of Antioxidant Activity}

A modified version of the FRAP assay described by Izzreen and Fadezelly (2013) was used to determine the antioxidant activity of collected samples as mg FeSO4/gr DW.

For the determination of antioxidant content of the samples as pre-treatment, $0.1 \mathrm{~g}$ of each dried sample was completed with methanol $(80 \%)$ to reach $10 \mathrm{ml}$ volume. Samples were mixed first in the water bath $\left(50^{\circ} \mathrm{C}\right)$ for a duration of 20 minutes and the samples were keep waiting after this procedure for $1 \mathrm{~h}$ in the dark. The mixture was centrifuged after that for a $20 \mathrm{~min}, 4000 \mathrm{cycle} / \mathrm{min}$ process for obtaining the extracts, which are used for the determination of phenolic content and antioxidant activity of the investigated samples.
Collected samples were analysed regarding their antioxidant activity values. White tea leaves were dried in the drying oven at $40^{\circ} \mathrm{C}$ and its antioxidant activity was determined using the UV-spectrophotometer by the FRAP method. The determination of antioxidant capacity of investigated samples (pre-treatments completed) was done using the FRAP method. The FRAP method bases on the colourization after the degradation of the $\mathrm{Fe}+3$ ion, bounded to TPTZ in an acid environment, to Fe+2. 300 $\mathrm{mM}$ acetate buffer ( $\mathrm{pH} 3,6), 10 \mathrm{mM}$ 2,4,6-tripyridyl-striazine (TPTZ) and $20 \mathrm{mM} \mathrm{FeCl3.6H2O}$ solutions were mixed at a proportion of 10:1:1 as FRAP (ferric reducing / antioxidant power) reactive to obtain a buffer solution. A FeSO4.H2O solution was used to prepare different standard probes to obtain a calibration curve. The final samples were obtained with a mix of $1980 \mu \mathrm{L}$ FRAP dispersive $+20 \mu \mathrm{L}$ sample and keep waiting after that for $3 \mathrm{~min} \mathrm{n}$ a ultrasonic shaker $\left(50^{\circ} \mathrm{C}\right)$. The measurements were done using a UV Spectrophotometer device at a wavelength of $595 \mathrm{~nm}$ to obtain the final absorbance values.

\section{Results and Discussion}

As far we know there no research about effect of organic fertilizer and drying methods on the phenolic content and antioxidant activity of white tea. If we talk about the chemical composition of tea we can say that it is complex and includes polyphenols, alkaloids (caffeine, theophylline and theobromine), amino acids, carbohydrates, proteins, chlorophyll, volatile compounds, minerals, trace elements and other unidentified compounds. Among these substances, mentioned polyphenols constitutes the most interesting group and are the main bioactive molecules in tea (Cabrera et al., 2003). The major polyphenolic compounds in tea are the flavan3ols called catechins which include: (-)-epicatechin (EC), ()-Epigallocatechin (EGC), (-)-epicatechin gallate (ECG), ()-epigallocatechingallate (EGCG), (-)-Gallocatechins (GC) and (-)-gallocatechin gallate (GCG). Catechins are present in large amounts in green tea (Peterson et al., 2005). Based on their chemical structure, catechins that contain three hydroxyl groups in the B ring (positions 3', 4' and 5') are called gallocatechins while gallic acid substitution in position 3 of the ring is characteristic of catechin gallate (Pellilo et al., 2008). Catechins account for $6-16 \%$ of the dry green tea leaves with EGCG constituting $10-50 \%$ of catechins and being the most potent due to its degree of gallation and hydroxylation (Stewart et al., 2009). TFs and TRs are another group of polyphenolic compounds found in both black and oolong teas (Oband et al., 2001). The tea beverage has continued to be considered a medicine since the ancient times because of its polyphenols. Research on the effects of tea on human health has been fuelled by the growing need to provide naturally healthy diets that include plant-derived polyphenols. In line with this, there is need to elucidate how known functional components in foods could expand the role of diet in disease prevention and treatment (Mandel et al., 2006). There is already growing evidence that tea polyphenols reduce the risk of heart diseases and cancer in humans (Vanessa and Williamson, 2004). In some studies, tea has been associated with antiallergic action (Jamamoto 
et al., 2004) and antimicrobial properties (Paola et al., 2005). Further studies have demonstrated that the coadministration of drugs with catechins (EC and EGCG) inhibits glucuronidation and sulfonation of orally administered drugs thereby increasing the bioavailability of such drugs (Hang et al., 2003). Moreover some epidemiological studies have associated consumption of tea with a lower risk of several types of cancer including those of the stomach, oral cavity, oesophagus and lungs (Cabrera et al., 2003; Hakim and Chow, 2004). Therefore, tea appears to be an effective chemo preventive agent for toxic chemicals and carcinogens

Statistical ANOVA analysis of total phenol content (mg GAE/g DW) of tea samples dried with different drying methods and obtained from organic fertilizer applications can be seen in Table 1, and corresponding total phenol content values can be seen in Graphic 1, in Table 2. The ANOVA analysis of phenolic content values of tea samples revealed high significant differences between drying methods, applied organic fertilizer doses and drying method $\mathrm{x}$ drying method interaction (Table 1).

Table 1 ANOVA of phenolic content white tea samples using values obtained from drying methods and organic fertilizer doses

\begin{tabular}{l|rrrr}
\hline \multicolumn{1}{c|}{ Source } & Degree of Freedom & Sum of Squares & Mean of Square & F \\
\hline Total & 44 & 27178.87 & & \\
Replication & 2 & 66.323 & 33.16 & 0.89 \\
Combination & 14 & 26075.76 & 1862.55 & $50.30^{* *}$ \\
Drying method (DM) & 2 & 9630.09 & 4815.04 & $130.04^{* *}$ \\
Organic fertilizer Dose(F) & 4 & 15406.86 & 3851.71 & $104.02^{* *}$ \\
DM $\times$ F & 8 & 1038.81 & 129.85 & $3.506^{*}$ \\
Error & 28 & 1036.77 & 37.027 & \\
\hline
\end{tabular}

$\mathrm{CV}=1.32 \%$

Table 2 Phenolic content values (mg GAE/g DW) of white tea samples obtained from different drying methods and organic fertilizer doses

\begin{tabular}{l|llllll}
\hline \multirow{2}{*}{ Drying Method } & \multicolumn{5}{|c}{ Fertilizer Doses } \\
\cline { 2 - 7 } & Control & $500 \mathrm{~kg} / \mathrm{ha}$ & $1000 \mathrm{~kg} / \mathrm{ha}$ & $1500 \mathrm{~kg} / \mathrm{ha}$ & $2000 \mathrm{~kg} / \mathrm{ha}$ & Mean \\
\hline Drying oven & $443.74^{\mathrm{fg}}$ & $462.93^{\mathrm{de}}$ & $479.66^{\mathrm{bc}}$ & $478.42^{\mathrm{bc}}$ & $506.29^{\mathrm{a}}$ & $474.21^{\mathrm{a}^{* * *}}$ \\
Shadow & $421.43^{\mathrm{i}}$ & $424.54^{\mathrm{hi}}$ & $435.68^{\mathrm{gh}}$ & $442.50^{\mathrm{g}}$ & $473.46^{\mathrm{cd}}$ & $439.52^{\mathrm{b}^{* *}}$ \\
Lyophilizator & $434.45^{\mathrm{gh}}$ & $454.88^{\mathrm{ef}}$ & $475.32^{\mathrm{bc}}$ & $473.46^{\mathrm{cd}}$ & $485.23^{\mathrm{b}}$ & $464.67^{\mathrm{a}^{* *}}$ \\
Mean & $433.20^{\mathrm{d}^{* *}}$ & $447.45^{\mathrm{c}^{* *}}$ & $463.55^{\mathrm{b}^{* *}}$ & $464.79^{\mathrm{b} * *}$ & $488.32^{\mathrm{a}^{* *}}$ & \\
\hline
\end{tabular}

*Means with the same letter are not significantly different from each other $(\mathrm{P}>0.05), * *$ Means with the same letter are not significantly different from each other $(\mathrm{P}>0.01)$

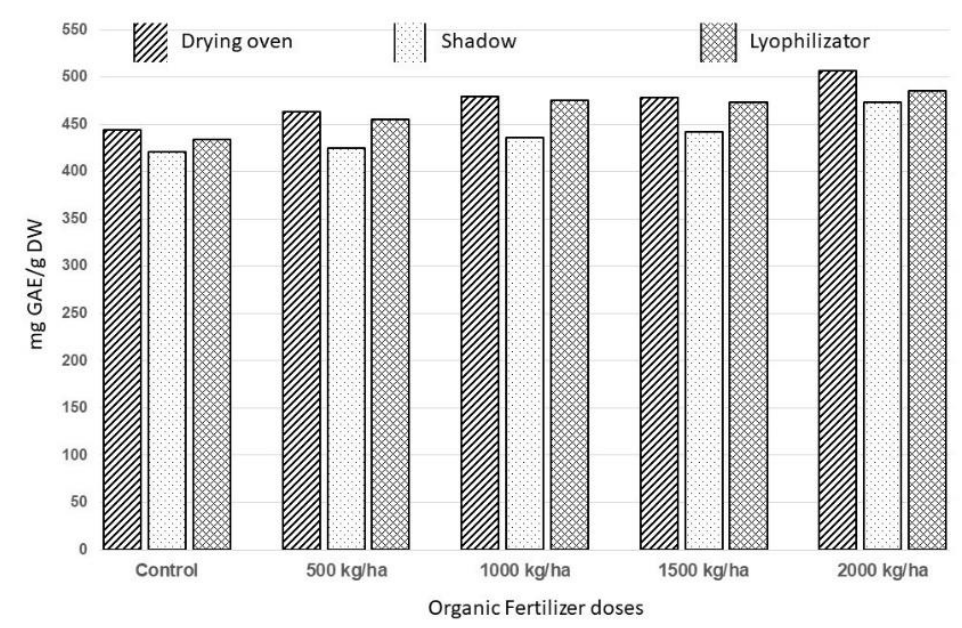

Graphic 1 Phenolic content of white tea samples obtained from different drying methods and organic fertilizer doses

The calculated coefficient of variation $(1.32 \%)$ is relatively low, because the allowed top level in field trials is $20 \%$.

The results showed that the phenolic content of white tea samples was as follows: 443.74- 508.15 mg GAE/g DW in the drying oven, $419.0-479.0 \mathrm{mg} \mathrm{GAE} / \mathrm{g} \mathrm{DW}$ in shadow and 431.35- $487.71 \mathrm{mg} \mathrm{GAE} / \mathrm{g} \mathrm{DW}$ in the lyophilizator (Table 2).
As can be seen in Table 2 and Graphic 1 total phenol content of white tea samples increased in every used drying method beginning from control up to every organic fertilizer dose of $500 \mathrm{~kg} / \mathrm{ha}, 1000 \mathrm{~kg} / \mathrm{ha}, 1500 \mathrm{~kg} / \mathrm{ha}$ and $2000 \mathrm{~kg} / \mathrm{ha}$. Drying oven and lyophilizator methods were located in the same group, differing from shadow drying. Regarding fertilizer doses the dose $2000 \mathrm{~kg} / \mathrm{ha}$ was very different from the other fertilizer doses, $1000 \mathrm{~kg} / \mathrm{ha}$ and 
$1500 \mathrm{~kg} / \mathrm{ha}$ were in the same group. The dose $500 \mathrm{~kg} / \mathrm{ha}$ and control were grouped separately in the groups $\mathrm{c}$ and $\mathrm{d}$ respectively.

Regarding drying method $\times$ organic fertilizer interaction the highest phenolic content value was obtained in samples applied with $2000 \mathrm{~kg} / \mathrm{ha}$ organic fertilizer and dried in the lyphilizator (506.29 mg GAE/g DW).

Shannon et al. (2017) compared the total phenolic content (TPC), total flavonoid content (TFC), ferric reducing antioxidant power (FRAP), DPPH radical scavenging capacity, and caffeine content of teas (black, green, white, chamomile, and mixed berry/hibiscus) over a range of infusion times $(0.5-10 \mathrm{mins})$ at $90^{\circ} \mathrm{C}$. In this study green tea had the highest total phenolic content of $557,58 \pm 74,98$; followed by black $499.19 \pm 46.56$; white $190.24 \pm 7.73$; berry $98.86 \pm 14.72$; and chamomile $75.31 \pm 3.65 \mu \mathrm{g}$ GAE/g tea. Unachukwu et al. (2010) quantified a TPC of $1.17 \mathrm{mg}$ GAE/g in green tea; and 0.96 $\mathrm{mg} \mathrm{GAE} / \mathrm{g}$ in white tea. In this study green tea was found to have the highest level of total phenolics (Komes et al., 2010; Anissi et al., 2012), followed by black tea; while the chamomile, berry, and white teas were significantly lower
$(\mathrm{P} \leq 0.05)$. White tea, although from the same $C$. sinensis plant as black and green varieties, may have a lower TPC due to the fact that oxidation by polyphenol oxidase is prevented in white tea processing (Astorino et al., 2014). Therefore, the phenolic monomers in the fresh leaves are not complexed into polyphenols such as catechins in green tea, or thearubigin in black tea. (Rusak et al., 2008) reported that the extraction of total phenolics from white tea leaves occurred at a significantly slower rate than that of other teas. The range of determined phenolic content was between 421.44 and 506.29 $\mu \mathrm{g}$ GAE/g DW for all applications and these values are higher as in above given values.

\section{Antioxidant Activity}

Statistical ANOVA analysis of antioxidant activity values (mg FeSO4/g DW) of tea samples dried with different drying methods and obtained from organic fertilizer applications can be seen in Table 3, and corresponding antioxidant values can be seen in Graphic 2, in Table 4.

Table 3 ANOVA of white tea samples using values obtained from drying methods and organic fertilizer doses

\begin{tabular}{l|rrrr}
\hline \multicolumn{1}{c|}{ Source } & Degree of Freedom & Sum of Squares & Mean Square & F \\
\hline Total & 44 & 74311.61 & & 0.218 \\
Replication & 2 & 17.80 & 8.90 & $40.667^{* *}$ \\
Drying Method (DM) & 2 & 3330.06 & 1665.03 & $222.77^{* *}$ \\
Organic Fertilizer Dose (F) & 4 & 36481.60 & 9120.40 & $101.78^{* *}$ \\
DM x F & 8 & 33335.79 & 4166.97 & \\
Error & 28 & 1146.35 & 40.94 & \\
\hline
\end{tabular}

$\mathrm{CV}=0.558 \%$

Table 4 Antioxidant activity values of white tea samples obtained from different drying methods and organic fertilizer doses

\begin{tabular}{|c|c|c|c|c|c|c|}
\hline \multirow{2}{*}{ DM } & \multicolumn{6}{|c|}{ Fertilizer Doses } \\
\hline & Control & $500 \mathrm{~kg} / \mathrm{ha}$ & $1000 \mathrm{~kg} / \mathrm{ha}$ & $1500 \mathrm{~kg} / \mathrm{ha}$ & $2000 \mathrm{~kg} / \mathrm{ha}$ & Mean \\
\hline DO & $1130.13^{i * *}$ & $1145.85^{\mathrm{gh}^{* *}}$ & $1161.96^{\mathrm{c}-\mathrm{f}^{* *}}$ & $1168.96^{\mathrm{bc}^{* *}}$ & $1176.89^{\mathrm{ab}^{* *}}$ & $1156.76^{\mathrm{a}^{* *}}$ \\
\hline S & $1141.23^{\mathrm{hi}^{* *}}$ & $1142.42^{\mathrm{hi}^{* *}}$ & $1145.59^{\mathrm{gh}^{* *}}$ & $1156.02^{\mathrm{e}-\mathrm{g}^{* *}}$ & $1157.08^{\mathrm{d}-\mathrm{g}^{* *}}$ & $1148.51^{\mathrm{b}^{* *}}$ \\
\hline $\mathrm{L}$ & $1005.31^{\mathrm{j} * *}$ & $1159.19^{\mathrm{c}-\mathrm{f}^{* * *}}$ & $1163.02^{\mathrm{c}-\mathrm{e}^{* *}}$ & $1168.30^{\mathrm{b}-\mathrm{d}^{* *}}$ & $1183.36^{\mathrm{a}^{* *}}$ & $1135.84^{\mathrm{c}^{* *}}$ \\
\hline Mean & $1092.22^{\mathrm{d}^{* *}}$ & $1149.15^{\mathrm{c}^{* *}}$ & $1156.86^{\mathrm{bc} * *}$ & $1164.43^{\mathrm{b}^{* *}}$ & $1242.44^{\mathrm{a}^{* *}}$ & \\
\hline
\end{tabular}

DM: Drying Method, DO: Drying oven, S: Shadow, L: Lyophilizator, **Means with the same letter are not significantly different from each other (P>0.01)

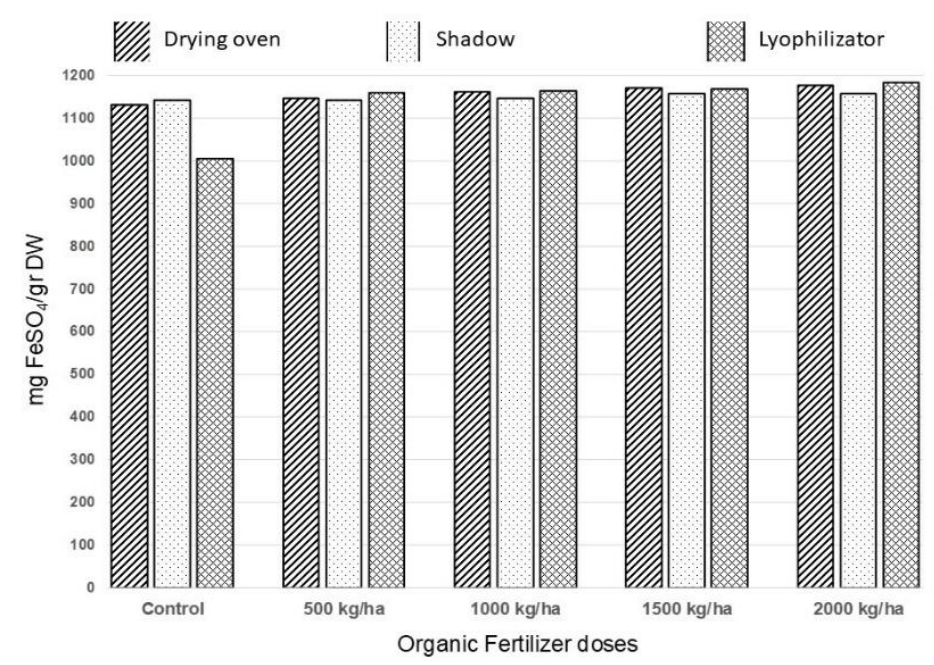

Graphic 2 Antioxidant capacity of white tea samples obtained from different drying methods and organic fertilizer doses 
The ANOVA analysis of antioxidant activity values of tea samples revealed very significant differences between drying methods, applied organic fertilizer doses and drying method $x$ drying method interaction (Table 3 ).

According to the FRAP method the antioxidant activity was as follows: $1124.585-1181.25 \mathrm{mg} \mathrm{FSO} 4 / \mathrm{gr} \mathrm{DW}$ in drying oven, 1132.907-1160.249 mg FSO4/gr DW in shadow and 997.3859-1185.609 $\mathrm{mg}$ FeSO4/gr DW in liyofilizator.

As can be seen in Table 4 and Graphic 2 antioxidant activity of white tea samples increased in every used drying method beginning from control up to every organic fertilizer dose of $500 \mathrm{~kg} / \mathrm{ha}, 1000 \mathrm{~kg} / \mathrm{ha}, 1500 \mathrm{~kg} / \mathrm{ha}$ and $2000 \mathrm{~kg} / \mathrm{ha}$.

All drying methods; drying oven, shadow and lyophilizator were grouped in the groups a, b and $\mathrm{c}$ respectively. Regarding statistical analysis results the fertilizer dose $2000 \mathrm{~kg} / \mathrm{ha}$ was determined as the most effectice dose in group a.

Natural antioxidants are increasingly appreciated by consumers due to both their inherent positive effects and to the possibility of using them as a source of natural additives to replace synthetic ones (Perumalla and Hettiarachchy, 2011; Gülçin, 2012; Oh et al., 2013; Silva-Weiss et al., 2013; Sevindik et al., 2017; Sevindik et al., 2018; Sevindik, 2019). Tea is a natural plant that is a rich source of natural antioxidants and provides a high free radical scavenger activity (Gramza and Korczak, 2005; Almajano et al., 2008). In our study antioxidant activity of white tea samples obtained from different drying methods and organic fertilizer doses showed high amounts of antioxidant activity.

\section{Conclusion}

Organic tea production will be a weak issue in Turkey in the future decades. Governmental institutions like ÇAYKUR and the private sector are searching for suitable and high yield performing organic fertilizers in Rize, Turkey. The primary focus is the income, which of course means total fresh leaf yield, of local farmers, because tea is the biggest income in this region.

But yield only is not sufficient for the production of different tea types, also their phenolic contents and antioxidant activity values are very important. In the present study the effect of different drying methods and organic fertilizers on the phenolic content and antioxidant activity of white tea were investigated for the first time in Rize, Turkey. Regarding both investigated quality characters $2000 \mathrm{~kg} / \mathrm{ha}$ was the best organic fertilizer dose, but the highest values regarding drying methods were obtained from the drying oven in all fertilizer doses considering phenolic content. If we look to obtained antioxidant activity values, it can be stated that all investigated samples displayed high amounts of these investigated quality character.

Based on obtained first year results it can be stated that high potential exists in organic tea production regarding the increase of phenolic content and antioxidant activity in tea. To develop arguments for the whole tea plantation area in Turkey, samples from different locations in these regions should be investigated.

\section{Acknowledgement}

The present study was conducted on the field with private means. For the quality analysis the laboratory facilities of the Faculty of Agriculture and Natural Sciences in Pazar, Rize/Turkey were used.

\section{References}

Almajano MP, Carbo R, Jimenez JAL, Gordon MH. 2014. Antioxidant and antimicrobial activities of tea infusions. Food Chemistry, 108: 55-63.

Anissi J, El Hassouni M, Ouardaoui A, Sendide KA. 2014. Comparative study of the antioxidant scavenging activity of green tea, black tea and coffee extracts: A kinetic approach. Food Chemistry, 150: 438-447.

Anomymous. 2016. Statistical Bulletin. ÇAYKUR.

Astorino T, Alkadhi K, Preedy VR. 2012. Caffeine: Chemistry, analysis, function and effects. Cambridge: Royal Society of Chemistry.

Ayuso MA, Pascal JA, Garcia C, Hernandez T. 1996. Evaluation of urban wastes for agricultural use. Soil Science and Plant Nutrition, 142 (1): 105-111.

Balentine DA, Wiseman SA, Bouwens LC. 1997. The Chemistry of Tea Flavonoids. Critical Reviews in Food Science and Nutrition, 37: 693-704.

Brancalião SR, Moraes MH. 2008. Alterações de alguns atributos físicos e das frações húmicas de um Nitossolo Vermelho na sucessão milheto soja em sistema plantio direto. Revista Brasileira de Cienca de Solo, 32, 393404.

Cabrera C, Gimenez R, Lopez CM. 2003. Determination of Tea Components with Antioxidant Activity. Journal of Agricultural and Food Chemistry, 51: 4427-4435.

Dias T, Gonçalo T, Teixeira NF, Alves M, Oliveira P, Silva B. 2013. White Tea (Camellia /sinensis (L.)): Antioxidant Properties and Beneficial Health Effects. International Journal of Food Science, Nutrition and Dietetics, 2: 1-15.

Graham HN. 1999. Tea. Wiley Encyclopedia of Food Science and Technology, John Wiley \& Sons: New York.

Gramza A, Korczak J. 2005. Tea constituents (Camellia sinensis L.) as antioxidants in lipid systems. Trends in Food Science and Technology, 16: 351-358.

Gülçin I. 2012. Antioxidant activity of food constituents: An overview. Archives of Toxicology, 86: 345-391.

Hakim IA, Chow SH. 2004. Green Tea, Polyphenol E and Cancer Prevention. In: Proceedings International Conference on Ocha (Tea) Culture and Science. Shizuoka. Japan.

Hicks A. 2001. Review of Global Tea Production and the Impact on Industry of the Asian Economic Situation. AU J.T. 5(2), October. Also in: Asian Int. Tea Conf. '98, Singapore: 1-2.

Hang L, Meng X, Chuvan I, Sang S, Patten C, Sheng S, Hung J, Winnik B, Yang S. 2003. Glucoronides of Tea Catechins: Enzymology of Biosynthesis and Biological Activities. Drug Metabolism and Disposition, 31: 452-461.

Hilal Y, Engelhardt U. 2007. Characterisation of white tea Comparison to green and black tea. Journal of Consumer Protection and Food Safety, 2: 414-421.

Izzreen MNNQ, Fadzelly ABM. 2013. Phytochemicals and antioxidant properties of different parts of Camellia sinensis leaves from sabah tea plantation in Sabah, Malaysia, International Food Research Journal, 20 (1): 307-312.

Komes D, Horžić D, Belščak A, Ganić KK, Vulić I. 2010. Green tea preparation and its influence on the content of bioactive compounds. Food Research International, 43 (1): 167-176.

Kosinska A, Andlauer W. 2014. Antioxidant Capacity of Tea: Effect of Processing and Storage. Processing and Impact on Antioxidants in Beverages. 
Lambert JD, Elias RJ. 2010. The Antioxidant and Pro-oxidant Activities of Green Tea Polyphenols: A role in Cancer Prevention. Archives of Biochemistry and Biophysics, 501: 65-72.

Latham EE. 1940. Relative productivity of the A horizon of a Cecil sandy loam and the $\mathrm{B}$ and $\mathrm{C}$ horizons exposed by erosion. American Society of Agronomy, 12: 950-954.

Mandel S, Packer L, Moussa YBH, Weireb O. 2006. Science of tea technology. Proceedings from the "Third International Conference on Mechanism and Action of Nutraceuticals. Journal of Nutrional Biochemistry, 16: 513-520.

Muktar H, Ahmad N. 2000. Tea polyphenols: prevention of cancer and optimizing health. American Journal of Clinical Nutrition, 71: 1698-1702.

Ning JM, Ding D, Song YS, Zhang ZZ, Luo X, Wan XC. 2016. Chemical constituents analysis of white tea of different qualities and different storage times. European Food Research and Technology, 12: 2093-2104.

Obanda M, Owuor PO, Mang'oka R. 2001. Changes in the Chemical and Sensory Quality Parameters of Black Tea due to Variations of Fermentation Time and Temperature. Journal of Food Chemistry, 75: 395-404.

Oh J, Jo H, Cho AR, Kim S, Han J. 2013. Antioxidant and antimicrobial activities of various leafy herbal teas. Food Control, 31: 403-409.

Owuor PO, Kwach BO. 2012. Quality and yields of black tea (Camellia sinensis L. O. Kuntze) in response to harvesting in Kenya: A review. Asian Journal of Biological and Life Sciences, 1 (1): 1-7.

Paola RD, Mazzon E, Muia C, Genovese T, Menegazzi M, Zaffini R, Suzuki H., Cuzzocrea S. 2005. Green Tea Polyphenols Attenuates Lung Injury in Carrageean-Induced Pleurisy Injury in Mice. Respiratory Research, 6: 1465-9921.

Pehlivan M, Sevindik M. 2018. Antioxidant and antimicrobial activities of Salvia multicaulis. Turkish Journal of Agriculture-Food Science and Technology, 6(5): 628-631.

Peiró S, Gordon MH, Blanco M, Pérez-Llamas F, Segovia F, Almajano MP. 2014. Modelling Extraction of White Tea Polyphenols: The Influence of Temperature and Ethanol Concentration. Antioxidants, 3(4): 684-99.

Pellilo M, Bendini AB, Toschi GT Vanzini M, Lercker G. 2002. Preliminary Investigation into Development of HPLC with UV and MSElectroscopy Detection for Analysis of Tea Catechins. Food Chemistry, 78: 369-374.

Perumalla AVS, Hettiarachchy NS. 2011. Green tea and grape seed extracts-Potential applications in food safety and quality. Food Research International, 44: 827-839.

Peterson J, Druyer J, Bhagwat S, Haytowitz D, Holden J, Eldridge AL, Beecher G, Ala-Desamni J. 2005. Major Flavonoids in Dry Tea. Journal of Food Composition and Analysis, 18: 487 501.

Sevindik M, Akgul H, Pehlivan M, Selamoglu Z. 2017. Determination of therapeutic potential of Mentha longifolia ssp. longifolia. Fresen Environ Bull, 26(7): 4757-4763.
Sevindik M. 2019. The novel biological tests on various extracts of Cerioporus varius. Fresenius Environmental Bulletin, 28(5): 3713-3717.

Queiroz FM, Matos AT, Pereira OG, Oliveira RA. 2004. Características químicas de solo submetido ao tratamento com esterco líquido de suínos e cultivado com gramíneas forrageiras. Cienca Rural, 34: 1487-1492.

Ren ZG, Chen YS, Tang FQ. 1999. Effect of inorganic fertilizer combined with organic manure on the microflora and enzyme activities in paddy soil. Plant Nutrition and Fertilizer Science, 2, 279-283.

Rusak G, Komes D, Likić S, Horžić D, Kovač M. 2008. Phenolic content and antioxidative capacity of green and white tea extracts depending on extraction conditions and the solvent used. Food Chemistry, 110 (4): 852-858.

Saha G, Choudhury SS, Berai B, Kumar PM. 2017. Biochemical and Microbiological Characterization of White Tea. IOSR Journal of Environmental Science, Toxicology and Food Technology, 11(5): 74-80.

Shamsul Islam, Hamid FS, Khawar A, Sumreen S, Qamar-uzZaman, Khanf N, Khan A, Shah BH. 2017. Effect of Organic Fertilizer on the Growth of Tea ((Camellia sinensis L.). International Journal of Sciences: Basic and Applied Research (IJSBAR): 1-9.

Shannon E, Jaiswal A, Abu-Ghannam N. 2017. Polyphenolic content and antioxidant capacity of white, green, black, and herbal teas: a kinetic study. Food Research, 2: 1-11.

Sharangi AB. 2009. Medicinal and therapeutic potentials of tea (Camellia sinensis L.) - a review. Food Research International, 42: 529-535.

Silva-Weiss A, Ihl M, Sobral PJA, Gómez-Guillén MC, Bifani V. 2013. Natural Additives in Bioactive Edible Films and Coatings: Functionality and Applications in Foods. Food Engineering Reviews 5: 200-216.

Stewart JA, Mullen W, Crozier A. 2004. On-line High Performance Liquid Chromatography of the Antioxidant of Phenolic in Green and Black Tea. Molecular Nutrition and Food Research, 49: 52-60.

Sun RL, Zhao BQ, Zhu LS. 2003. Effects of long-term fertilization on soil enzyme activities and its role in adjustingcontrolling soil fertility. Plant Nutrition and Fertilizer Science, 9: 406-410.

Unachukwu UJ, Ahmed S, Kavalier A, Lyles JT, Kennelly EJ. 2010. White and green teas (Camellia sinensis var. sinensis): variation in phenolic, methylxanthine, and antioxidant profiles. Journal of Food Science, 75 (6): 541-548.

Vanessa C, Williamson GA. 2004. Review of the Health Effects of Green Tea Catechins in in-vivo Animal Models. Journal of Nutrition, 134: 3431-3440.

Yamamoto MM, Inagaki N, Kitaura J, Chikumoto T, Kawahara H, Kawakami Y, Kawakami T. 2004. Nagai, H. OMethylated Catechins from Tea Leaves Inhibit Multiple Protein Kinases in Mast Cells. Journal of Immunology, 172: 4486-4492. 